\title{
Chemical and agronomic development of Kalanchoe brasiliensis Camb. and Kalanchoe pinnata (Lamk.) Pers under light and temperature levels
}

\author{
BRUNA P. CRUZ ${ }^{1}$, LUCIANA M. CHEDIER ${ }^{1}$, RODRIGO L. FABRI ${ }^{2}$ and DANIEL S. PIMENTA ${ }^{1}$ \\ ${ }^{1}$ Departamento de Botânica, Instituto de Ciências Biológicas, Universidade Federal de Juiz de Fora, \\ Rua José Lourenço Kelmer s/n, São Pedro, 36036-900 Juiz de Fora, MG, Brasil \\ ${ }^{2}$ Departamento de Bioquímica, Instituto de Ciências Biológicas, Universidade Federal de Juiz de Fora, \\ Rua José Lourenço Kelmer s/n, São Pedro, 36036-900 Juiz de Fora, MG, Brasil \\ Manuscript received on June 24, 2010; accepted for publication on January 1, 2011
}

\begin{abstract}
This study compares the development of Kalanchoe brasiliensis and Kalanchoe pinnata, which are medicinal species known as "saião" and "folha da fortuna" that are used interchangeably by the population for medicinal purposes. The experiment consisted of 20 plots/species planted in plastic bags with homogeneous substrate in a randomized design, which grown under light levels $(25 \%, 50 \%, 70 \%$, full sunlight) at environment temperature, and a treatment under a plastic with greater temperature range than the external environment. It was obtained for $K$. pinnata a greater plant height, total length of sprouts, stems, production and dry matter content of leaves than that obtained for K. brasiliensis, which achieved higher averages only for the length of lateral branches. The species showed increases in height, which varied in inverse proportion to the light, and it was observed the influence of temperature in $K$. pinnata. The production and dry matter content of leaves were proportional to the luminosity; the same occurred in the thickness of leaves for $K$. brasiliensis. In the swelling index and Brix degree, K. brasiliensis showed higher averages than K. pinnata. In relation to the total content of flavonoids it was not observed significant differences for both species. The analyzed parameters showed the main differences in the agronomic development of the two species.
\end{abstract}

Key words: Kalanchoe, luminosity, mucilage, flavonoids.

\section{INTRODUCTION}

Kalanchoe Adans. is one of the three most important medicinal genera of the Crassulaceae family and comprises about 125 species, such as Kalanchoe brasiliensis Camb., which is native of Brazil, and Kalanchoe pinnata (Lamk.) Pers., which is native of Madagascar (Costa et al. 2008). The species of the Crassulaceae family present xeromorphic features of adaption to intense luminosity and water scarcity (Herrera 2008).

The medicinal species $K$. brasiliensis and $K$. pinnata are known in Brazil as "saião" and "folha da fortuna", respectively, and are used throughout the country to treat coughs, boils, gastritis and adnexitis

Correspondence to: Daniel Sales Pimenta

E-mail: daniel.pimenta@ufjf.edu.br
(Lorenzi and Matos 2008). In experimental pharmacology, Veiga Jr. (2005) mentioned the following activities identified in preclinical tests in vivo and/or in vitro for both species: analgesic, anti-inflammatory, antileishmaniasis, antimalarial, antimicrobial, antipyretic, antitumor, anti-ulcer, uterine contraction inhibitor, hepatoprotective, immunosuppressive and pesticide.

Several characteristics, such as plant form, physiology and resource allocation, vary according to the irradiance level to which the plants are acclimated and/or ecologically restricted (Givnish 1988). Thus, changes in light levels to which a species is adapted may result in different physiological responses in its biochemical, anatomical and growth characteristics (Atroch et al. 2001) 
The most important chemical class found in the species of the genus Kalanchoe is represented by flavonoids (Costa et al. 2008). There is a well-established positive correlation between the intensity of light radiation and the production of phenolic substances such as flavonoids, tannins and anthocyanins (Gobbo-Neto and Lopes 2007). In the specific case of the flavonoids, they are mainly accumulated in superficial tissues and used by the plant as filters against ultraviolet (UV) radiation. It is also important to notice that plants are able to adapt to a considerable temperature range in which variations occur yearly, monthly and daily. This factor plays a major role in its development, affecting therefore its production of special metabolites (Gobbo-Neto and Lopes 2007).

The heterogeneous polysaccharides mucilages are natural constituents of the plant that have swelling properties in the presence of water (Poser 2004). The leaves of $K$. brasiliensis and $K$. pinnata possess various properties like the mucilaginous one (Kamboj and Saluja 2009, Machado and Melo-Junior 2009). An ordinary example of a medicinal plant that is commercially used and fits in the same situation is Aloe vera, which, according to Bach and Lopes (2007), has the inside of its leaves formed by a parenchymatous tissue that is rich in polysaccharides (mucilage).

Despite remarkable medicinal uses, $K$. brasiliensis and $K$. pinnata have been little studied and are often used without distinction by the population (Costa et al. 2008). Based on these problems, the aim of this study was to compare the development of these two species through chemical and agronomic parameters such as plant height, total length of sprouts, branches and stems, production and dry matter content of leaves, herbal use, thickness of leaves and production of flavonoids, mucilage and soluble solids.

\section{MATERIALS AND METHODS}

\section{Plant Material and Growth Conditions}

Seedlings of the studied species at the same stage of development, which were obtained in a garden of the Faculdade de Farmácia e Bioquímica, Universidade Federal de Juiz de Fora (UFJF), Brazil, were planted in plastic bags with 5 liters of homogeneous substrate consisting of soil/sand/manure $(3: 1: 1)$ and placed in a botanical station at Universidade Federal de Juiz de Fora, Brazil. Voucher specimens (K. pinnata: 46575/ K. brasiliensis: 43980) are kept in the Herbarium Leopoldo Krieger (CESJ) of UFJF. The plots were grown under four light levels $(25 \%, 50 \%, 70 \%$ and full sunlight) at environment temperature using black screens of polyethylene, shade type, plus a cultivation treatment under polypropylene transparent plastic, ring fenced, in a microenvironment with higher temperatures than the external environment: $2-3^{\circ} \mathrm{C}$ on cloudy days and $6-8^{\circ} \mathrm{C}$ on sunny days, during the day, and below the environment temperature $1-5^{\circ} \mathrm{C}$ overnight.

\section{Measurements and Analytical Determinations}

Using a luxmeter (Chauvin Arnoux ${ }^{\circledR}$ CA 810), the lux of the treatments in days of sun and shade was measured considering the value obtained for the treatment under full sunlight on a sunny day as $100 \%$ (Table I). With one plant per plot, all five treatments were randomly evaluated for about six months in four replications resulting in 20 plots for species and a total of 40 plots.

TABLE I

Lux of treatments $(25 \%, 50 \%$ and $70 \%$ of light, plastic (P) and full sunlight (FS)) on days of sun and shade.

\begin{tabular}{c|c|c|c}
\hline Treatment* & $\begin{array}{c}\text { Days } \\
\text { of sun }\end{array}$ & $\begin{array}{c}\text { Days } \\
\text { of shade }\end{array}$ & $\begin{array}{c}\text { Differences } \\
\text { between them }\end{array}$ \\
\hline $25 \%$ & $24.41 \%$ & $16.3 \%$ & $8.11 \%$ \\
$50 \%$ & $40.26 \%$ & $24.23 \%$ & $16.03 \%$ \\
$70 \%$ & $63.18 \%$ & $40.07 \%$ & $23.11 \%$ \\
P & $85.74 \%$ & $50.32 \%$ & $35.42 \%$ \\
FS & $100 \%$ & $61.97 \%$ & $38.03 \%$ \\
\hline \multicolumn{3}{|c}{ * }
\end{tabular}

The collection was performed earlier for plots grown under plastic due to the increased senescence presented. The others were performed soon after, always grouped by replicates for the standardization of the analysis. On the days of collection, the plant height, total length of sprouts (tillers per vessel), lateral branches (branches of the main stem) and total length of stems (sum of previous measures) were measured.

To obtain an estimate of the total production of dry leaves, the dry matter content was determined by the ratio of dry to fresh weight. An aliquot of the 
leaves was weighed immediately after collection (fresh weight) and then dried in an oven at $70^{\circ} \mathrm{C}$ to obtain the dry weight. This content was multiplied by the total fresh weight of leaves of each plot.

The thickness of leaf blades was determined by performing fresh freehand cross-sections in the intercostals region of the middle portion of the first fully expanded leaf from the stem apex of both species. The leaf material was fixed in AFA (alcohol, formaldehyde and acetic acid 9:0,5:0,5 v/v) for subsequent sectioning. Using a light microscope (Olympus BX-41), it was measured the thickness of the mesophyll and counted the number of cells in the vertical thickness line in the fundamental parenchyma, in the midvein region.

The amount of total flavonoids was determined as previously described by Fabri et al. (2009) with slight modifications. Quercetin (Sigma, 98\% pure) was used as the standard for the calibration curve. One milligram of dried plant samples was extracted by maceration with two milliliters of methanol and filtered. One milliliter of each extract $(0.5 \mathrm{mg} / \mathrm{ml})$ was mixed with $2 \%$ aluminum trichloride $(1 \mathrm{ml})$ and one drop of acetic acid. The mixture was diluted with methanol to $25 \mathrm{ml}$ and allowed to stand for $40 \mathrm{~min}$ at $20^{\circ} \mathrm{C}$ and then its absorbance was measured at $415 \mathrm{~nm}$. Blank solution was prepared from the plant samples $(1 \mathrm{mg})$ and one drop of acetic acid diluted to $25 \mathrm{ml}$ in methanol. All determinations were performed in triplicates. The total amount of flavonoids was expressed in $\mathrm{mg} / \mathrm{g}$ plant samples in quercetin equivalents.

The content of mucilage was obtained through the swelling index of dry leaves according to the method of Farmacopéia Brasileira (2000), with some modifications. It was used $0.5 \mathrm{~g}$ of dried leaves ground into fragments of approximately $2 \mathrm{~mm}$. These fragments were placed into bottles with $12 \mathrm{~mm}$ of internal diameter and added $3 \mathrm{ml}$ of water. After 1 hour stirring at every ten minutes and three hours without stirring, the rate of swelling was determined by the final average volume occupied by fragments minus the initial volumes. The Brix degree (content of soluble solids) was measured in the previous experiment with a manual refractometer (Instrutherm ${ }^{\circledR}$ RT-280, $0^{\circ}$ Brix to $90^{\circ}$ Brix) in the supernatant liquid 24 hours after the measurement of the swelling index (Izidoro et al. 2008).

\section{STATISTICAL ANALYSis}

The results were analyzed by ANOVA, followed by Tukey test for averages in the factorial design of both species and five treatments, totalizing 10 factors. By using four replicates, 40 plots were analyzed. The data were described as significantly different, with $5 \%$ of significance.

\section{RESULTS}

Through the data of vegetative growth of both species, it was observed that plots of $K$. pinnata showed a significantly greater plant height, total length of sprouts and stems, production and dry matter content of leaves than the plots of $K$. brasiliensis, which reached higher averages only for the length of lateral branches (Table II). It was noted therefore in $K$. pinnata a greater apical dominance, tillering and an increased production of stems and leaves.

Both species showed increases in height, which varied in an inverse proportion to the incidence of light. The treatment with $25 \%$ of light showed significantly higher averages than the ones with $70 \%$, full sunlight and cultivation under plastic. In treatments with 70 and $50 \%$ of light were found higher averages than under full sunlight and plastic. Unfolding the factorial design and analyzing the treatments within each species, it was found a greater influence of the temperature (cultivation under plastic) in $K$. pinnata, which showed lower heights in this treatment.

The emergence of sprouts was about 5,9 times higher in $K$. pinnata than in K. brasiliensis. Moreover, the branching of the stems was approximately 10 times higher in K. brasiliensis, which increased with shading. These results show a significant vegetative difference between both species. The estimated total production of dry leaves was directly proportional to luminosity, with a higher amplitude in K. pinnata. In K. brasiliensis, cultivation under plastic drastically affected the total production of dry leaves, which justified the early collection of plots under this treatment, as described in the methodology. By analyzing the dry matter content of leaves, it was realized that the species also showed direct response to light. This content was higher in cultivation under plastic than in other treatments for $K$. 
TABLE II

Plant height (PH), total length of sprouts (LSP), total length of lateral branches (LLB), total length of stems (LST), total estimated production of dry leaves (PDL) and dry matter content of leaves (DMCL) of plots of Kalanchoe brasiliensis (Kb) and Kalanchoe pinnata (Kp) in treatments (TR) under full sunlight (FS), 70\% (70), 50\% (50), $25 \%$ (25) of light and under plastic (P).

\begin{tabular}{|c|c|c|c|c|c|c|c|c|c|c|c|c|}
\hline & & $\begin{array}{l}\mathrm{PH} \\
(\mathrm{cm})\end{array}$ & & $\begin{array}{l}\text { LSP } \\
(\mathrm{cm})\end{array}$ & & $\begin{array}{l}\text { LLB } \\
(\mathrm{cm})\end{array}$ & & $\begin{array}{l}\text { LST } \\
(\mathrm{cm})\end{array}$ & & $\begin{array}{c}\text { PDL } \\
(\mathrm{g})\end{array}$ & & $\begin{array}{c}\text { DMCL } \\
(\%)\end{array}$ \\
\hline \multicolumn{13}{|l|}{ Total: } \\
\hline $\mathrm{Kb}$ & & $60.62 \mathrm{a}$ & & $29.92 \mathrm{a}$ & & $126.32 \mathrm{~b}$ & & $216.87 \mathrm{a}$ & & $16.72 \mathrm{a}$ & & $6.09 \mathrm{a}$ \\
\hline $\mathrm{Kp}$ & & $85.32 \mathrm{~b}$ & & $176.20 \mathrm{~b}$ & & $12.50 \mathrm{a}$ & & $274.02 \mathrm{~b}$ & & $43.21 \mathrm{~b}$ & & $10.19 \mathrm{~b}$ \\
\hline \multirow{5}{*}{ TR } & $\mathrm{P}$ & $60.62 \mathrm{a}$ & 70 & $82.37 \mathrm{a}$ & FS & $45.50 \mathrm{a}$ & $P$ & $217.25 \mathrm{a}$ & 25 & $21.77 \mathrm{a}$ & 25 & $7.01 \mathrm{a}$ \\
\hline & FS & $62.00 \mathrm{a}$ & 50 & $98.37 \mathrm{ab}$ & $\mathrm{P}$ & $53.19 \mathrm{ab}$ & FS & $231.75 \mathrm{a}$ & 50 & $28.51 \mathrm{~b}$ & 50 & $7.54 \mathrm{ab}$ \\
\hline & 70 & $77.37 \mathrm{~b}$ & $\mathrm{P}$ & $103.44 \mathrm{ab}$ & 50 & $63.69 \mathrm{ab}$ & 70 & $236.94 \mathrm{a}$ & 70 & $30.88 \mathrm{~b}$ & 70 & $8.05 \mathrm{bc}$ \\
\hline & 50 & $80.25 \mathrm{bc}$ & 25 & $106.87 \mathrm{ab}$ & 70 & $77.19 \mathrm{~b}$ & 50 & $242.31 \mathrm{a}$ & $P$ & $31.14 \mathrm{~b}$ & FS & $8.70 \mathrm{~cd}$ \\
\hline & 25 & $84.62 \mathrm{c}$ & FS & $124.25 \mathrm{~b}$ & 25 & $107.50 \mathrm{c}$ & 25 & $299.00 \mathrm{~b}$ & FS & $37.51 \mathrm{c}$ & $\mathrm{P}$ & $9.41 \mathrm{~d}$ \\
\hline \multirow{5}{*}{$\mathrm{Kb}$} & FS & $44.12 \mathrm{a}$ & 70 & $17.00 \mathrm{a}$ & FS & $72.75 \mathrm{a}$ & FS & $157.12 \mathrm{a}$ & $P$ & $10.17 \mathrm{a}$ & 50 & $4.80 \mathrm{a}$ \\
\hline & $\mathrm{P}$ & $52.50 \mathrm{~b}$ & 50 & $24.00 \mathrm{a}$ & $\mathrm{P}$ & $105.87 \mathrm{ab}$ & $\mathrm{P}$ & $191.25 \mathrm{ab}$ & 25 & $11.62 \mathrm{a}$ & 25 & $5.29 \mathrm{a}$ \\
\hline & 70 & $61.25 \mathrm{c}$ & $\mathrm{P}$ & $32.87 \mathrm{a}$ & 50 & $127.25 \mathrm{bc}$ & 50 & $221.50 \mathrm{~b}$ & 50 & $17.12 \mathrm{ab}$ & 70 & $5.71 \mathrm{a}$ \\
\hline & 50 & $70.25 \mathrm{~d}$ & 25 & $35.50 \mathrm{a}$ & 70 & $144.00 \mathrm{c}$ & 70 & $222.25 \mathrm{~b}$ & 70 & $19.81 \mathrm{bc}$ & FS & $6.11 \mathrm{a}$ \\
\hline & 25 & $75.00 \mathrm{~d}$ & FS & $40.25 \mathrm{a}$ & 25 & $181.75 \mathrm{~d}$ & 25 & $292.25 \mathrm{c}$ & FS & $24.88 \mathrm{c}$ & $\mathrm{P}$ & $8.55 \mathrm{~b}$ \\
\hline \multirow{5}{*}{$\mathrm{Kp}$} & $\mathrm{P}$ & $68.75 \mathrm{a}$ & 70 & $147.75 \mathrm{a}$ & 50 & $0.12 \mathrm{a}$ & $\mathrm{P}$ & $243.25 \mathrm{a}$ & 25 & $31.93 \mathrm{a}$ & 25 & $8.74 \mathrm{a}$ \\
\hline & FS & $79.87 \mathrm{~b}$ & 50 & $172.75 \mathrm{ab}$ & $\mathrm{P}$ & $0.50 \mathrm{a}$ & 70 & $251.62 \mathrm{ab}$ & 50 & $39.90 \mathrm{~b}$ & $\mathrm{P}$ & $10.27 \mathrm{~b}$ \\
\hline & 50 & $90.25 \mathrm{c}$ & $\mathrm{P}$ & $174.00 \mathrm{ab}$ & 70 & $10.37 \mathrm{a}$ & 50 & $263.12 \mathrm{ab}$ & 70 & $41.95 \mathrm{~b}$ & 50 & $10.27 \mathrm{~b}$ \\
\hline & 70 & $93.50 \mathrm{c}$ & 25 & $178.25 \mathrm{ab}$ & FS & $18.25 \mathrm{a}$ & 25 & $305.75 \mathrm{~b}$ & FS & $50.14 \mathrm{c}$ & 70 & $10.39 \mathrm{~b}$ \\
\hline & 25 & $94.25 \mathrm{c}$ & FS & $208.25 \mathrm{~b}$ & 25 & $33.25 \mathrm{a}$ & FS & $306.37 \mathrm{~b}$ & $P$ & $52.12 \mathrm{c}$ & FS & $11.29 \mathrm{~b}$ \\
\hline
\end{tabular}

Averages followed by the same letters in columns do not differ at $5 \%$ of probability by Tukey test.

brasiliensis, while $K$. pinnata presented smaller average than in the other four treatments under $25 \%$ of light.

It was observed for $K$. brasiliensis a higher increased thickness of leaves under full sunlight than under 50 and $25 \%$ of light (Table III). It was also noted a greater number of cells regarding the measurement of the line thickness.

In measuring the swelling index of leaves and Brix degree for both species, K. brasiliensis presented higher averages than $K$. pinnata (Table IV). The decrease of luminous intensity in both species induced a lower swelling index of leaves (Table IV), a lower thickness of leaves (Table III) and a lower dry matter content (Table II), as previously mentioned. These results indicate that these treatments influence the leaf's content of mucilage for both species.

Through the content of total flavonoids, no significant differences were obtained between the averages of both species (Table IV). Although these results did not differ significantly, K. pinnata showed higher averages than $K$. brasiliensis and both presented higher values under full sunlight.

\section{DISCUSSION}

According to Taiz and Zeiger (2004), plants are able to adapt to different light conditions due to the presence of phytochrome, which perceives the shade. They then allocate a greater share of their resources to height growth. Zanella et al. (2006) found similar responses to those of $K$. pinnata and $K$. brasiliensis for Passiflora edulis Sims f. flavicarpa, which increased plant height progressively with the intensity of shading.

Scalon et al. (2001) suggested that plants under high light availability have increased the thickness of their leaves as a resource for the protection of photosynthetic pigments, which can increase the total dry weight. This was also observed for $K$. brasiliensis. If this increase in thickness did not correspond to an increase in the number of cells, it may be supposed that 
TABLE III

Thickness of leaf blades (TB) and number of cells in thickness line (NC) of plots of Kalanchoe brasiliensis $(\mathrm{Kb})$ and Kalanchoe pinnata $(\mathrm{Kp})$ in treatments (TR) under full sunlight (FS), 70\% (70), 50\% (50) and 25\% (25) of light and under plastic (P).

\begin{tabular}{c|ll|ll}
\hline & & $\begin{array}{c}\text { TB } \\
(\mathrm{mm})\end{array}$ & & \multicolumn{1}{c}{$\mathrm{NC}$} \\
\hline $\begin{array}{c}\text { Total: } \\
\mathrm{Kb}\end{array}$ & & $0.62 \mathrm{~b}$ & & $21.10 \mathrm{~b}$ \\
$\mathrm{Kp}$ & & $0.43 \mathrm{a}$ & & $15.00 \mathrm{a}$ \\
\hline & 25 & $0.43 \mathrm{a}$ & 25 & $15.75 \mathrm{a}$ \\
& 50 & $0.46 \mathrm{a}$ & 50 & $16.87 \mathrm{ab}$ \\
$\mathrm{TR}$ & $\mathrm{P}$ & $0.54 \mathrm{ab}$ & $\mathrm{P}$ & $17.12 \mathrm{ab}$ \\
& 70 & $0.57 \mathrm{ab}$ & 70 & $19.25 \mathrm{bc}$ \\
& $\mathrm{FS}$ & $0.63 \mathrm{~b}$ & $\mathrm{FS}$ & $21.25 \mathrm{c}$ \\
\hline & 50 & $0.47 \mathrm{a}$ & 25 & $17.75 \mathrm{a}$ \\
& 25 & $0.53 \mathrm{a}$ & 50 & $18.50 \mathrm{a}$ \\
$\mathrm{Kb}$ & $\mathrm{P}$ & $0.63 \mathrm{ab}$ & $\mathrm{P}$ & $19.50 \mathrm{ab}$ \\
& 70 & $0.65 \mathrm{ab}$ & 70 & $22.25 \mathrm{~b}$ \\
& FS & $0.83 \mathrm{~b}$ & FS & $27.50 \mathrm{c}$ \\
\hline & 25 & $0.34 \mathrm{a}$ & 25 & $13.75 \mathrm{a}$ \\
& FS & $0.42 \mathrm{a}$ & $\mathrm{P}$ & $14.75 \mathrm{a}$ \\
$\mathrm{Kp}$ & 50 & $0.45 \mathrm{a}$ & FS & $15.00 \mathrm{a}$ \\
& $\mathrm{P}$ & $0.45 \mathrm{a}$ & 50 & $15.25 \mathrm{a}$ \\
& 70 & $0.48 \mathrm{a}$ & 70 & $16.25 \mathrm{a}$ \\
\hline
\end{tabular}

Averages followed by the same letters in columns do not differ at $5 \%$ of probability by Tukey test.

the swelling of the cells was due to higher mucilage content present in vacuoles. Fleshy plants like Crassulaceae developed this xeromorphic adaptive characteristic (Fahn and Cutler 1992).

Although the results of total flavonoids did not corroborate significantly the expected response, the influence of light on the production of flavonoids is widely discussed in the literature, which acts in the protection against photo-destruction by absorbing and/or dissipating the solar energy, thus hindering the UV-B damage to more internal tissues (Gobbo-Neto and Lopes 2007). An example of this was evidenced by Pimenta (unpublished data) for a medicinal plant named Echinodorus macrophyllus (Kunth) Micheli, which had the highest production of flavonoids and arylpropanoids when grown under full sunlight during the spring. Muzitano et al. (2011) evidenced the response of flavonoids to solar radiation for K. pinnata. In their study, the flavonoid content increased significantly under sunlight when compared with an extract obtained from K. pinnata specimens collected in the same season (autumn), but growing in the shade.

Nielsen et al. (2005) studied the content of flavonoids in flowers of 16 Kalanchoe blossfeldiana Poelln. varieties, and the higher amount obtained was of 0,099 $\mathrm{mg} / \mathrm{g}$ of quercetin. This value is lower than the lowest value obtained in the present study for $K$. brasiliensis and $K$. pinnata, which was of $92,29 \mathrm{mg} / \mathrm{g}$.

In conclusion, there was a greater apical dominance and tiller in K. pinnata, besides an increased production of stems and leaves. In K. brasiliensis, there was higher branching of stems. The intensity of light directly affected both species regarding production and dry matter content of leaves, and inversely affected height growth, which also showed to be influenced by temperature in K. pinnata. K. brasiliensis showed thicker leaves under full sunlight and higher swelling index and content of soluble solids than $K$. pinnata. Finally, it was not observed significant differences for both species concerning the content of flavonoids. This study therefore contributes to the differentiation and the agronomy research of both species and will be relevant to pharmacological activities attributed to mucilage.

\section{ACKNOWLEDGMENTS}

The authors would like to thank "Pró Reitoria de Pesquisa da Universidade Federal de Juiz de Fora" (PROPESQ-UFJF) for the financial support.

\section{RESUMO}

Este estudo compara o desenvolvimento de Kalanchoe brasiliensis e Kalanchoe pinnata, espécies medicinais conhecidas como "saião" e "folha da fortuna" que são utilizadas indiferenciadamente pela população para fins medicinais. O experimento consistiu em 20 parcelas/espécie plantadas em sacos plásticos com substrato homogêneo, em delineamento ao acaso, cultivadas sob níveis de luminosidade $(25 \%, 50 \%, 70 \%$, luz plena) em temperatura ambiente, e um tratamento sob plástico com maior amplitude térmica que o meio externo. Obtevese para $K$. pinnata maiores alturas de plantas, comprimentos totais de brotos, caules, produção e teor de matéria seca de folhas que para $K$. brasiliensis, que alcançou maiores médias apenas para comprimentos de ramos laterais. As espécies 
TABLE IV

Swelling index (SI), Brix degree (BD) and total flavonoids (TF)

of plots of Kalanchoe brasiliensis (Kb) and Kalanchoe pinnata (Kp)

in treatments (TR) under full sunlight (FS), 70\% (70), 50\% (50)

and $25 \%(25)$ of light and under plastic (P).

\begin{tabular}{|c|c|c|c|c|c|c|}
\hline & & $\begin{array}{c}\text { SI } \\
(\mathrm{mm})\end{array}$ & & $\begin{array}{c}\text { BD } \\
\left({ }^{\circ} \text { Brix }\right)\end{array}$ & & $\begin{array}{c}\mathrm{TF} \\
(\mathrm{mg} / \mathrm{g})\end{array}$ \\
\hline \multicolumn{7}{|l|}{ Total: } \\
\hline $\mathrm{Kb}$ & & $0.74 \mathrm{~b}$ & & $4.81 \mathrm{~b}$ & & $171.00 \mathrm{a}$ \\
\hline $\mathrm{Kp}$ & & $0.60 \mathrm{a}$ & & $3.43 \mathrm{a}$ & & $187.67 \mathrm{a}$ \\
\hline \multirow[t]{5}{*}{ TR } & 25 & $0.52 \mathrm{a}$ & 25 & $3.90 \mathrm{a}$ & $\mathrm{P}$ & $131.88 \mathrm{a}$ \\
\hline & $\mathrm{P}$ & $0.59 \mathrm{ab}$ & $\mathrm{P}$ & $4.02 \mathrm{a}$ & 50 & $146.98 \mathrm{a}$ \\
\hline & 70 & $0.71 \mathrm{bc}$ & FS & $4.16 \mathrm{a}$ & 70 & $192.40 \mathrm{a}$ \\
\hline & 50 & $0.76 \mathrm{bc}$ & 50 & $4.19 \mathrm{a}$ & 25 & $208.23 \mathrm{a}$ \\
\hline & FS & $0.78 \mathrm{c}$ & 70 & $4.34 \mathrm{a}$ & FS & $217.19 \mathrm{a}$ \\
\hline \multirow[t]{5}{*}{$\mathrm{Kb}$} & 25 & $0.59 \mathrm{a}$ & 25 & $4.25 \mathrm{a}$ & $\mathrm{P}$ & $92.29 \mathrm{a}$ \\
\hline & $\mathrm{P}$ & $0.65 \mathrm{ab}$ & 70 & $4.75 \mathrm{a}$ & 50 & $129.58 \mathrm{a}$ \\
\hline & 70 & $0.76 \mathrm{ab}$ & $\mathrm{P}$ & $4.95 \mathrm{a}$ & 25 & $201.67 \mathrm{a}$ \\
\hline & 50 & $0.79 \mathrm{ab}$ & 50 & $5.00 \mathrm{a}$ & 70 & $211.87 \mathrm{a}$ \\
\hline & FS & $0.90 \mathrm{~b}$ & FS & $5.10 \mathrm{a}$ & FS & $219.58 \mathrm{a}$ \\
\hline \multirow[t]{5}{*}{$\mathrm{Kp}$} & 25 & $0.45 \mathrm{a}$ & $\mathrm{P}$ & $3.10 \mathrm{a}$ & 50 & $164.38 \mathrm{a}$ \\
\hline & $\mathrm{P}$ & $0.54 \mathrm{ab}$ & FS & $3.22 \mathrm{a}$ & $\mathrm{P}$ & $171.46 \mathrm{a}$ \\
\hline & 70 & $0.65 \mathrm{ab}$ & 50 & $3.37 \mathrm{a}$ & 70 & $172.92 \mathrm{a}$ \\
\hline & FS & $0.65 \mathrm{ab}$ & 25 & $3.55 \mathrm{a}$ & 25 & $214.79 \mathrm{a}$ \\
\hline & 50 & $0.73 \mathrm{~b}$ & 70 & $3.92 \mathrm{a}$ & FS & $214.79 \mathrm{a}$ \\
\hline
\end{tabular}

Averages followed by the same letters in columns do not differ at $5 \%$ of probability by Tukey test.

apresentaram aumento em altura que variou em proporção inversa à incidência luminosa, e observou-se a influência da temperatura em $K$. pinnata. A produção e teor de matéria seca de folhas foram proporcionais à luminosidade; o que também ocorreu na espessura foliar para K. brasiliensis. No índice de intumescência e grau Brix, $K$. brasiliensis apresentou maiores médias que $K$. pinnata. Em relação ao teor de flavonoides totais, não foram observadas diferenças significativas para ambas as espécies. Os parâmetros analisados apontaram as principais diferenças no desenvolvimento agronômico das duas espécies.

Palavras-chave: Kalanchoe, luminosidade, mucilagem, flavonoides.

\section{REFERENCES}

Atroch EMAC, Soares AM, Alvarenga AA And Castro EM. 2001. Crescimento, teor de clorofilas, distribuição de biomassa e características anatômicas de plantas jovens de Bauhinia forficata Link. submetidas à diferentes condições de sombreamento. Rev Cienc Agrotec 25: 853-862.
BACH DB AND LOPES MA. 2007. Estudo da viabilidade econômica do cultivo da babosa (Aloe vera L.). Rev Cienc Agrotec 31: 1136-1144.

Costa SS, Muzitano MF, Camargo LMM and CouTINHO MAS. 2008. Therapeutic Potential of Kalanchoe species: Flavonoids and other Secondary Metabolites. Nat Prod Com 3: 2151-2164.

FAbri RL, Nogueira MS, Braga FG, COIMBra ES AND SCIO E. 2009. Mitracarpus frigidus aerial parts exhibited potent antimicrobial, antileishmanial, and antioxidant effects. Bioresource Technol 100: 428-433.

FAHn A And Cutler DF. 1992. Xerophytes. Berlin, Stuttgart: Gebrüder Borntraeger, p. 99-100.

FARMACOPÉIA BRASILEIRA. 2000. $4^{\text {th }}$ ed., São Paulo: Editora Atheneu Ltda.

GIVNISH TJ. 1988. Adaptation to sun and shade: A wholeplant perspective. Aust J Plant Physiol 15: 63-92.

GobBo-Neto L AND Lopes NP. 2007. Plantas medicinais: Fatores de influência no conteúdo de metabólitos secundários. Quim Nova 30: 374-381. 
HERRERA A. 2008. Crassulacean acid metabolism and fitness under water deficit stress: if not for carbon gain, what is facultative CAM good for? Ann Bot 103: 645-653.

IZIDORO DR, SCHEER AP, NEGRE MFO, HAMINIUK CWI AND SIERAKOWSKI MR. 2008. Avaliação físico-química, colorimétrica e aceitação sensorial de emulsão estabilizada com polpa de banana verde. Rev Inst Adolfo Lutz 67: $167-176$

KAMBoj A AND SAluJA AK. 2009. Bryophyllum pinnatum (Lam.) Kurz.: Phytochemical and pharmacological profile: A review. Phcog Rev 3: 364-374.

LORENZI H AND MATOS FJA. 2008. Plantas medicinais no Brasil: Nativas e Exóticas, $2^{\text {nd }}$ ed., Nova Odessa: Instituto Plantarum, p. 223-224.

Machado MCFP And Melo-Junior MR. 2009. Avaliação do efeito antitumoral da Kalanchoe brasiliensis sobre o sarcoma 180 em camundongos. Rev Eletr Farm 6: 1-6.

Muzitano MF, Bergonzi MC, De Melo Go, Lage CLS, BILIA AR, VINCIERI FF, ROSSI-BERGMANN B AND COSTA SS. 2011. Influence of cultivation conditions, season of collection and extraction method on the content of antileishmanial flavonoids from Kalanchoe pinnata. J Ethnopharmacol 133: 132-137.
Nielsen AH, Olsen CE AND Møller BL. 2005. Flavonoids in flowers of 16 Kalanchoë blossfeldiana varieties. Phytochemistry 66: 2829-2835.

Poser GL von. 2004. Polissacarídeos. In: Simões CMO et al. (Orgs), Farmacognosia: da planta ao medicamento, Porto Alegre/Florianópolis: Editora UFRGS/UFSC, p. 504-505.

SCALON SPQ, Filho HS, Rigoni MR and Veraldo F. 2001. Germinação e crescimento de mudas de pitangueira (Eugenia uniflora L.) sob condições de sombreamento. Rev Bras Frutic 23: 652-655.

TAIZ L AND ZEIGER E. 2004. Fisiologia Vegetal. $3^{\text {a }}$ ed., Porto Alegre: Artmed, p. 411-412.

VeIgA JR VF. 2005. Kalanchoe brasiliensis Camb. e Kalanchoe pinnata (Lamk.) Pers. In: AMARAL ACF et al., Coletânea científica de plantas de uso medicinal, Rio de Janeiro: Editora FIOCRUZ, p. 103-124.

ZANElla F, SONCELA R AND Lima ALS. 2006. Formação de mudas de maracujazeiro amarelo sob níveis de sombreamento em Ji-Paraná/RO. Rev Cienc Agrotec 30: 880-884. 